\title{
Preface: Insights and advances in Iberian ichthyology
}

\author{
Javier Sánchez-Hernández ${ }^{\circledR}$ - Rufino Vieira-Lanero • David José Nachón • \\ Sandra Barca $\cdot$ María del Carmen Cobo $\cdot$ Fernando Cobo
}

Received: 16 January 2022 / Revised: 16 January 2022 / Accepted: 21 January 2022 / Published online: 15 February 2022

(C) The Author(s), under exclusive licence to Springer Nature Switzerland AG 2022

Keywords Fish biology · Iberian fish · Ichthyofauna

The Iberian ichthyofauna involves a total of 901 species including 4 jawless, 102 cartilaginous, and 795 bony fish species across freshwater, estuaries and seas (Fauna Ibérica project; http://www.fauna-iberi ca.mncn.csic.es/english/faunaib/). The baseline of the Iberian ichthyology was due to the endeavor of Félix António de Brito Capello (1828-1879), José Vicente

Handling editor: Sidinei M. Thomaz

Guest editors: Javier Sánchez-Hernández \& RufinoVieiraLanero / Insights and Advances in Iberian Ichthyology

J. Sánchez-Hernández $(\bowtie)$

Área de Biodiversidad y Conservación, Departamento de Biología y Geología, Física y Química Inorgánica, Universidad Rey Juan Carlos, Móstoles, Madrid, Spain e-mail: javier.sanchezh@urjc.es

\section{R. Vieira-Lanero}

Estación de Hidrobioloxía "Encoro do Con", Universidade de Santiago de Compostela, 36617 Vilagarcía de Arousa, Spain

D. J. Nachón · S. Barca $\cdot$ F. Cobo

Departamento de Zooloxía, Xenética e Antropoloxía Física, Facultade de Bioloxía, Universidade de Santiago de Compostela, 15782 Santiago de Compostela, Spain

M. del Carmen Cobo

Department of Biological Science, University of Alabama, Tuscaloosa, AL 35487, USA
Barbosa du Bocage (1823-1907), José Cornide (1734-1803), and Franz Steindachner (1834-1919) (Jordan, 1902; Doadrio, 2001; Lobón-Cerviá, 2001). These ichthyologists inspired others, such as Luis Lozano Rey (1878-1958) and Fernando de Buen y Lozano (1895-1962), to pursue research advances about Iberian ichthyology during its early stage of knowledge on this matter. However, it was not until the 1980s that a greater depth and progress in ichthyology was achieved thanks to the emergence of new generations of ichthyologists, who are currently leading the Iberian research groups dedicated to advances in research in different branches of fish biology (Doadrio, 2001; Lobón-Cerviá, 2001). Today, ichthyology has an undisputed interest among Iberian researchers devoted to exploring all aspects of fish biology, fisheries and management from riverine to estuarine and marine biomes. This great interest in ichthyology drove the creation of the Iberian Society of Ichthyology (SIBIC) in 2010.

Although the SIBIC was created in 2010, several Iberian congresses on Ichthyology had already been held years before. Thus, the first Iberian Congress of Ichthyology was carried out in 1981, and there were two more congresses (1983 and 1991). In July of 2012, the SIBIC hosted the IV Iberian Congress of Ichthyology (Girona, Spain) and every two years since that meeting, the "SIBIC family" has convened to share research on fish biology and conservation. The current Themed Section is exclusively devoted to research on ichthyology and includes a selection 
of papers presented during the VIII Iberian Congress of Ichthyology, held from 15 to 19 July 2020 in Santiago de Compostela (Spain). Because of the COVID19 pandemic, all the scientific content of VIII Iberian Congress of Ichthyology was transmitted online. The VIII Iberian Congress of Ichthyology focused on multiple disciplines and brought together circa 120 scientists and managers mostly from Iberian countries but some from other countries.

The scientific program was composed by three plenary seasons (Pao Fernández Garrido, Pedro Morais, and Luis Cardona) and a total of 105 presentations grouped into 7 thematic areas (Table 1). Pao Fernández Garrido (World Fish Migration FoundationWFMF) gave a talk entitled "Connecting fish, rivers and people: Making a change from local to global" about the main projects (e.g., Dam Removal Europe project) carried out by the WFMF on dam demolition and restoration of longitudinal river connectivity. Pedro Morais (Centre of Marine Sciences-CCMAR) presented an extensive review of the conservation efforts of Iberian fish with special attention on endangered and vulnerable Ichthyofauna "Taking the lead on the conservation efforts of Iberian fish: a challenge to SIBIC." Luis Cardona (University of Barcelona) gave the last plenary conference entitled "Stable isotopes as habitat tracers in fish ecology" and presented exciting insights into the potential use of stable isotopes as habitat tracers to enhance our understanding in fish ecology. The last day included two workshops about alien species within the actions of the project Life Invasaqua and ended with the ordinary general assembly of the SIBIC. The winner of the award "Premio de la Cátedra Luís de Camões" for the best student presentation was Cármen Sousa for her talk entitled "Evolution of the immune system in two antarctic notothenioids."

Some notable results of the VIII Iberian Congress of Ichthyology are presented in this Themed Section with two guest editors, Javier Sánchez-Hernández and Rufino Vieira-Lanero, who managed the peer review process. This Themed Section covers various aspects of marine and freshwater fish biology that were presented at this congress such as fish migration (García-Vega et al., 2021), conservation status (Miqueleiz et al., 2021), swimming performance (Sánchez-González et al., 2021) and population structure (Schroeder et al., 2021). It should be noted that this Themed section presents papers of the meeting, and that although most papers covered the Iberian Peninsula (García-Vega et al., 2021; Miqueleiz et al., 2021; Sánchez-González et al., 2021), there is one focused on Brazilian fishery grounds (Schroeder et al., 2021).

We thank the many anonymous reviewers for their time and expertise per-reviewing the submitted articles, which improved the quality of the papers. The diverse array of communications presented at the VIII Iberian Congress of Ichthyology furthered our knowledge about Iberian Ichthyology. However, given the increasing impact on anthropogenic disturbance on the Iberian ichthyofauna in addition to the outdated assessments of the Iberian fish species (Doadrio et al., 2011; Maceda-Veiga, 2013; Miqueleiz et al.,

Table 1 Thematic areas of the VIII Iberian Congress of Ichthyology held from 15 to 19 July 2020 in Santiago de Compostela (Spain)

\begin{tabular}{|c|c|c|c|c|}
\hline \multirow[t]{2}{*}{ Thematic areas } & \multirow[t]{2}{*}{ Talks $(n)$} & \multirow[t]{2}{*}{ Posters $(n)$} & \multicolumn{2}{|c|}{ Themed Section } \\
\hline & & & Papers $(n)$ & Reference \\
\hline I. Ecology and biodiversity & 13 & 8 & 1 & García-Vega et al. (2021) \\
\hline II. Environment and conservation & 9 & 6 & 2 & $\begin{array}{l}\text { Miqueleiz et al. (2021); } \\
\text { Sánchez-González et al. } \\
\text { (2021) }\end{array}$ \\
\hline $\begin{array}{l}\text { III. Genetics, development, parasitism and } \\
\text { ecophysiology }\end{array}$ & 8 & 12 & 0 & - \\
\hline IV. Fisheries and aquaculture & 5 & 7 & 0 & - \\
\hline V. Non-Iberian scope & 4 & 15 & 1 & Schroeder et al. (2021) \\
\hline VI. Invasive alien marine species & 5 & 5 & 0 & - \\
\hline VII. Projects & 2 & 6 & 0 & - \\
\hline
\end{tabular}

$n=$ number of talks/posters/papers 
2021), more attention needs to be paid in the future to fish management and conservation efforts, in order to successfully cope with biodiversity and habitat loss.

Author contributions JSH led the writing. All authors read and approved the final manuscript.

Funding No funds, grants, or other support was received.

Availability of data and material Not applicable.

\section{Declarations}

Conflict of interest The authors declare no conflicts of interest.

Ethical approval Not applicable.

Consent to participate Not applicable.

\section{References}

Doadrio, I. 2001. Origen y evolución de la ictiofauna continental española. In Doadrio, I. (ed), Atlas y libro rojo de los peces continentales de España. Dirección General de Conservación de la Naturaleza, Museo Nacional de Ciencias Naturales, Madrid: 19-34.

Doadrio, I., S. Perea, P. Garzón-Heydt, \& J. L. González, 2011. Ictiofauna continental española. Bases para su seguimiento. Dirección General de Medio Natural y Política Forestal. MARM, Madrid.

García-Vega, A., J. F. Fuentes-Pérez, F. J. Bravo-Córdoba, J. Ruiz-Legazpi, J. Valbuena-Castro \& F. J. Sanz-Ronda, 2021. Pre-reproductive movements of potamodromous cyprinids in the Iberian Peninsula: when environmental variability meets semipermeable barriers. Hydrobiologia. https://doi.org/10.1007/s10750-021-04537-6.

Jordan, D. S., 1902. The history of ichthyology. Science 16: 241-258.

Lobón-Cerviá, J., 2001. Entre ríos y peces, 20 años de intensa investigación. In Doadrio, I. (ed), Atlas y libro rojo de los peces continentales de España. Dirección General de Conservación de la Naturaleza, Museo Nacional de Ciencias Naturales, Madrid: 35-40.

Maceda-Veiga, A., 2013. Towards the conservation of freshwater fish: Iberian Rivers as an example of threats and management practices. Reviews in Fish Biology and Fisheries 23: $1-22$.

Miqueleiz, I., R. Miranda, A. H. Ariño \& T. Cancellario, 2021. Effective reassessments of freshwater fish species: a case study in a Mediterranean peninsula. Hydrobiologia. https://doi.org/10.1007/s10750-021-04644-4.

Sánchez-González, J. R., F. Morcillo, J. Ruiz-Legazpi \& F. J. Sanz-Ronda, 2021. Fish morphology and passage through velocity barriers. Experience with northern straight-mouth nase (Pseudochondrostoma duriense Coelho, 1985) in an open channel flume. Hydrobiologia. https://doi.org/10. 1007/s10750-021-04712-9.

Schroeder, R., P. R. Schwingel \& A. T. Correia, 2021. Population structure of the Brazilian sardine (Sardinella brasiliensis) in the Southwest Atlantic inferred from body morphology and otolith shape signatures. Hydrobiologia. https://doi.org/10.1007/s10750-021-04730-7.

Publisher's Note Springer Nature remains neutral with regard to jurisdictional claims in published maps and institutional affiliations. 